\title{
SATISFACTION ANALYSIS OF ROSE CULTIVATORS TOWARDS MARSHAL 200 EC (CASE STUDY AT GUNUNGSARI VILLAGE, BUMIAJI DISTRICT, BATU CITY)
}

\author{
Matthew Howard Lambert ${ }^{*}$, Ratya Anindita ${ }^{1}$, Condro Puspo Nugroho ${ }^{1}$ \\ ${ }^{1}$ Brawijaya University in Malang, East Java, Indonesia \\ *corresponding author: howardmatt264@gmail.com
}

\begin{abstract}
The objective of this research is to describe the reason of continuous buying decision and to analyze consumer satisfaction of roses cultivators towards Marshal 200 EC. The methods used for data analysis are Importance-Performance Analysis (IPA) and Customer Satisfaction Index (CSI). Five processes of buying decision considered are needs recognition, information seeking, alternative evaluation, purchase decision, and post-purchase behavior. There are also three main indicators employed to describe the buying decision, which are sociocultural environment, consumer psychology, and marketing efforts. Eight indicators of a product, such as performance, features, conformity, durability, serviceability, aesthetics, and perceived quality, are used to measure the consumers' satisfaction. The research samples are 33 roses cultivators. The result of buying decision describes that products association, information sources, shop selection, and future buying possibilities influence buying decision. The result of IPA method are 85.9 percent of consumers' suitability level; therefore, it needs to be improved. The result of CSI are 60.21 percent of satisfaction level, which is in average satisfied category.
\end{abstract}

Keywords: usage guidelines, buying decision, consumers satisfaction, insecticides attributes

\section{INTRODUCTION}

Roses are floricultural commodities which have high economical value and lots of potential since there are constant demand from European Union and United States (France AgriMer,2013). Unfortunately, Indonesian rose cultivators are not quite adept to maximize its potential and still having low productions (Sutater and Effendie, 2016). Production could be maximized by proper maintenance technique such as the application of the right insecticides (Hafizah, 2014). Application of the right insecticides considering the attacking pest in accordance to usage guidelines (Djojosumarto, 2008).

Based on field observations, the frequent pest of rose commodities is white mealybugs (Pseudococcus sp.). The majority of rose cultivators at Gunungsari Village in the late years were using
Marshal 200 EC which have been considered good to overcoming the white mealybugs problems.

Consumer satisfaction is the trends of the late centuries. Its wide range usefulness from company's benefits to academic learning purposes have been recognized (Tjiptono and Diana, 2015). A lot of researches found that consumer satisfaction was mostly determined by the quality of products or services offered (Bitner, 1990). Both satisfaction or dissatisfaction of consumers take effect on its future buying probabilities and the buying behavior of the potential consumers (Yustitia, 2009). Understanding the farmer satisfaction would help to broaden the people view of farmer perspectives.

There have been many researchers about consumer satisfaction on agricultural related products (Batt and Liu, 2012; Cerjak et al, 2014; and Capitello et al, 2015). There are journals specified for using the Index Performance Analysis (IPA) and 
Customer Satisfaction Index (CSI) (Rizzuto and Etemad-Sajadi, 2013; and Mustikarini et al, 2014). The differences on this research are these research specified on satisfaction in misfunctioning product and applied in agricultural production. In this case, the product is Marshal 200 EC.

The objective of this research are (1) to describes the reasons of the continuous buying decision of rose cultivators towards the usage of Marshal 200 EC, (2) to analyze the importance and performance of the attributes on the Marshal 200 EC from cultivators' perspectives, and (3) to analyze the whole satisfaction level of cultivators on Marshal $200 \mathrm{EC}$.

\section{RESEARCH METHODS}

This research is conducted at Gunungsari Village, Batu City. The reason of selecting this location is due to the fact that Gunungsari Village are the production center of rose in East Java province. Moreover, the majority of the rose cultivators at Gunungsari Village have been using the Marshal 200 EC.

Type of data used in this research are primary data which are coming from in-depth interview results with respondents. The respondens are selected using purposive sampling, in other words the samples that being chosen are those who use Marshal 200 EC insenticide. The samples are 33 roses cultivators, in consideration that cultivators on samples have been buying Marshal 200 EC regularly in the last 2 years.

\section{Buying Decision Analysis}

Buying decision analysis of rose cultivators at Gunungsari Village which is used in this research is quantitative descriptive only. The main purpose for using this analysis is because the objective of this research only to describes the reasoning for its buying decision, and not measuring the effect value of each factors that rose cultivators stated. In order to use the quantitative descriptive of the buying decision, the process of buying decision made by Schiffman and Kanuk (2008) were used as depicted in Figure 1.

There are five stages on buying decision. These stages are needs recognitions, pre-purchase research/information seeking, alternative evaluation, buying decision, and post-purchase evaluation/behavior. All of these stages are both affecting and affected by the main indicators of buying decision, complexly intertwining each other. The main indicators are sociocultural environements, consumers' psychology, and marketing efforts. This analysis will be measuring rose cultivators answers on the in-depth interview about the main indicators that are included by rose cultivators answers in each buying decision stages.

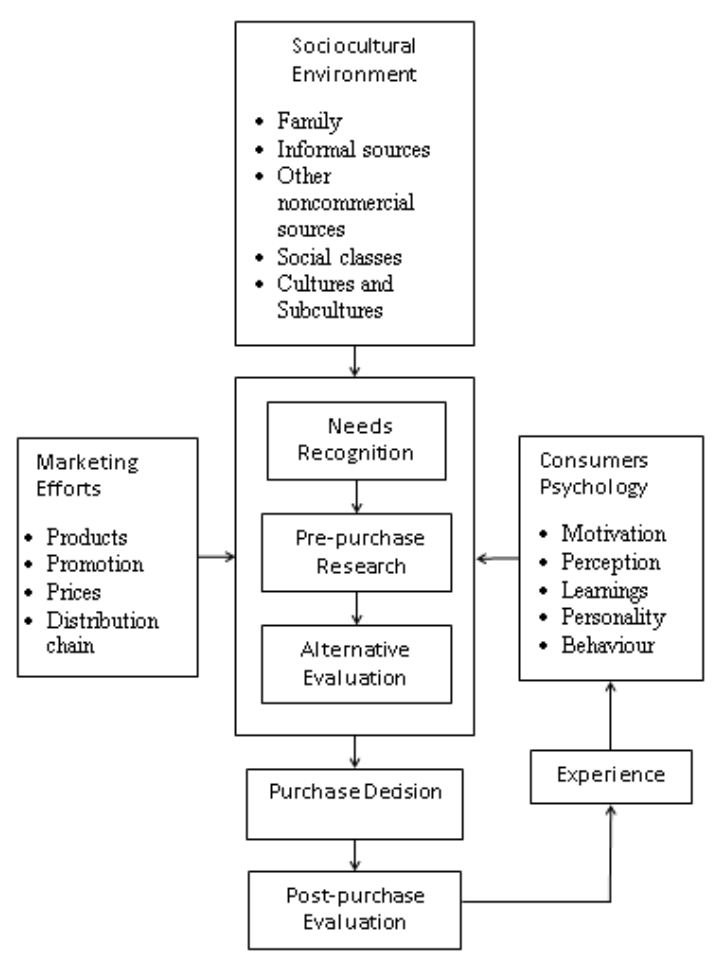

Figure 1. Buying Decision Process

(Schiffman and Kanuk, 2008)

\section{Consumers Satisfaction Analysis}

Satisfaction analysis of rose cultivators at Gunungsari Village in this research uses Importance-Performance Analysis (IPA) and Customer Satisfaction Index (CSI). The instrument test is conducted before used in term of its validity and reliability. The reliability test must show that the $\mathrm{r}$-calculate is higher than the r-tables and the reliability test must show the Cronbach Alpha's value is higher than 0,6 (Simamora, 2002).

\section{Importance-Performance Analysis (IPA)}

The measurements of consumers' satisfaction analysis are indicated by eight dimensions of satisfaction attributes which are performance, features, reliability, conformity, durability, service ability, aesthetics, and perceived quality (Tjiptono and Chandra, 2008). Process of the IPA are:

1) Comparing the importance and performance to measure the suitability level. The equation to the comparisons is

$$
P R_{i}=\frac{x_{i}}{y_{i}} \times 100 \%
$$


Details:

PRi is s the suitability level of rose cultivators towards insecticide $\mathrm{X}$ attributes through comparisons of Marshal 200 EC performance attributes scores (Xi) with its importance counterpart (Yi).

2) Measuring the mean importance level and mean performance level with equations

$\overline{\mathrm{X}}=\frac{\sum_{i=1}^{n} x_{i}}{\mathrm{n}}, \overline{\mathrm{Y}}=\frac{\sum_{\mathrm{i}=1}^{\mathrm{n}} y_{i}}{\mathrm{n}}$

Mean performance level $(\bar{X})$ and mean importance level $(\overline{\mathrm{Y}})$ measured by comparing the total performance scores of each attributes (Xi) and the total importance scores of each attributes $(\mathrm{Yi})$ with its total samples of rose cultivators (n).

3) Mean performance level of total attributes will be the basis of $x$-axis, intersecting horizontally with the mean importance level of total attributes which is the basis of y-axis in a Cartesian diagram

4) Both mean importance level of performance and importance will place each attributes to its appropriate quadran as shown in Figure 2.

Importance

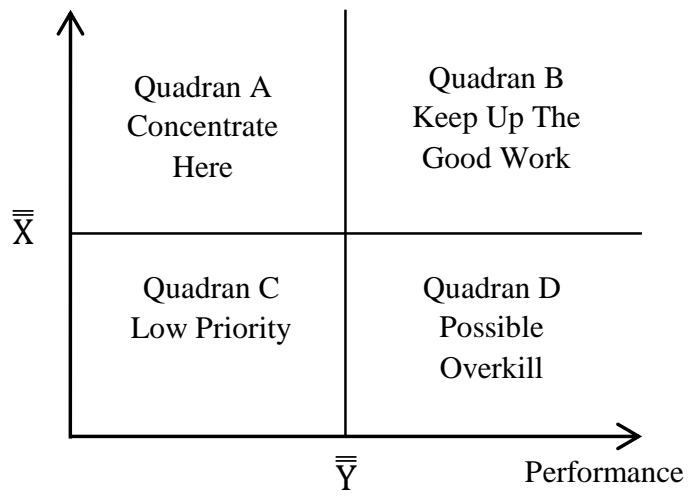

Figure 2. Cartesius Diagram of IPA

\section{Customer Satisfaction Index (CSI)}

Customer Satisfaction Index is used to measure the consumer satisfaction both on importance and performance the whole attributes of the product which useful for company's internal purpose. Process of CSI are:

1) Measuring Mean Importance Score (MIS). MIS is average value of importance on each attributes. The equation is

$$
\text { MIS }=\frac{\sum_{\mathrm{i}=1}^{\mathrm{n}} \mathrm{Yi}}{\mathrm{n}}
$$

MIS is measured by dividing the importance score of each attributes (Yi) with its total samples of rose cultivators (n).

2) Measuring Weighing Factors (WF). WF is the percentage value of MIS that each attribute has towards the whole value of MIS. The equation is

$$
\mathrm{WFi}=\frac{\mathrm{MISi}}{\sum \mathrm{MIS}} \times 100 \%
$$

WF is measured by dividing the MIS value of each attributes of Marshal 200 EC to its total, multiplied in 100 percent.

3) Measuring Mean Satisfaction Scores (MSS). MSS is average value of performance on each attributes. The equation is

$\operatorname{MSS}=\frac{\sum_{\mathrm{i}=1}^{\mathrm{n}} \mathrm{Xi}}{\mathrm{n}}$

MSS value is measured by dividing performance of each attributes $(\mathrm{Xi})$ with its total samples of rose cultivators (n).

4) Measuring Weight Scores (WS), which is the satisfaction vaue of each attributes. WS value is measured by multiplication of importance of each attributes (WF) times the average value of performance (MSS).

5) Measuring whole satisfaction on product (CSI). The equation is

$\mathrm{CSI}=\frac{\sum \mathrm{WS}}{\mathrm{HS}} \times 100 \%$

CSI is measured by dividing whole satisfaction level (WS) with its highest scale ratio (HS) which is 5 .

According to Riandina and Suryana (2006), the CSI value can be interpreted into five categories which are:

1) 81 to 100 percent is included in very satisfied category

2) 66 to 80 percent is included in satisified category

3) 51 to 65 percent is included in average satisfied category

4) 35 to 50 percent is included in less satisfied category

5) 0 to 34 percent is incuded in not satisfied category

\section{RESULTS AND DISCUSSION}

\section{Buying Decision of Rose Cultivators}

According to Schiffman and Kanuk (2008), buying decision process is devided into five stages which are needs recognition, information seeking/prepurchase research, alternative evaluation, buying decision, and post-purchase evaluation. There are 3 main factors that both affected and affecting these stages, which are sociocultural environment, consumers' psychology, and marketing efforts.

Buying decision analysis of Marshal 200 EC will be made in descriptive, hence only respondent's answer that correlate to main factors which most affecting or affected by each buying decision stages that being described. 
Only in fourth stage out of the remaining five that respondents mention answers that correlate to main factors. The consumers mostly answer that friends and relatives affect the most decision in seeking information (21 percent). For the alternative evaluation, most answers are efficient/potent (45 percent) and suitable/precisely fit (21 percent). Both of them are included in products association.

The shop selection contributes the most buying decision in purchase decision stage. The respondents answer for purchase decision mainly revolves on economical psychological motives, such as nearer location (45 percent) and cheaper than others (15 percent) for economical motives. For the psychological motives, most respondents' answer are consumer and seller connection (12 percent) and firm belief towards the shop (15 percent). In postpurchase evaluation which assuming the future buying possibilities if the price rises, the respondents mostly still buy the product ( 57 percent).

Although different from the products-wise, the research conducted by Rizzuto and Etemad-Sajadi (2013) also stated that brand name and impression play in pivotal roles towards satisfaction. Brand impression also known as products association. In the other hand, the results from this research is different from research conducted by Cerjak et al (2014). In Croatia, consumers tend to more favorable or more in terms with eco-friendly products. Therefore, this practice in this research of overused chemicals in agriculture would be lower in demand rather than other research.

\section{Importance and Performance of Attributes}

Table 1 . The Attributes Suitability

\begin{tabular}{cllr}
\hline No & Indicators & Attributes & $\begin{array}{c}\text { Suitability } \\
\text { Level } \\
(\text { PRi) }(\%)\end{array}$ \\
\hline 1 & Capability & Dependability & 83.33 \\
2 & Features & $\begin{array}{l}\text { Volume } \\
\text { variations }\end{array}$ & 77.98 \\
3 & Reliability & $\begin{array}{l}\text { Distribution } \\
\text { permit }\end{array}$ & 78.16 \\
& Conformity & Usage & 100 \\
4 & instructions & \\
& & Expired time & 94.92 \\
6 & Durability & Complaints & 98.47 \\
& ability & management & 91.17 \\
7 & & Availability & 53.79 \\
8 & Aesthetics & Authencity sign & 76.42 \\
9 & Perceived & Price & 101.56 \\
10 & quality & Brand name & 92.08 \\
11 & & Company & \\
& & reputation & 85.9 \\
\hline
\end{tabular}

The suitability level of performance and importance measured through comparison between performance and importance of each attributes. The suitability scores of each attributes determines the suitability of the rose cultivators felt towards Marshal 200 EC. The suitability level is one of the factors that determines the satisfaction on each attributes, varies on each attributes.

As depicted in Table 1, it can be concluded that on most attributes the importance score are bigger than the performance. According to suitability category of Supranto (2011), the total suitability Marshal 200 EC is below 100 percent hence included in less satisfying category. For the sub category, included in less satisfied category since the toal score is 85.9 percent. Its proven by the attributes which at 100 percent or higher are only usage instructions and brand name.

The results show the total scores of attributes mean performance is 2.97 and mean importance is 3.46. Both mean of performance and importance used as $\mathrm{X}$ axis for performance and $\mathrm{Y}$ axis for importance on Cartesius Diagram.

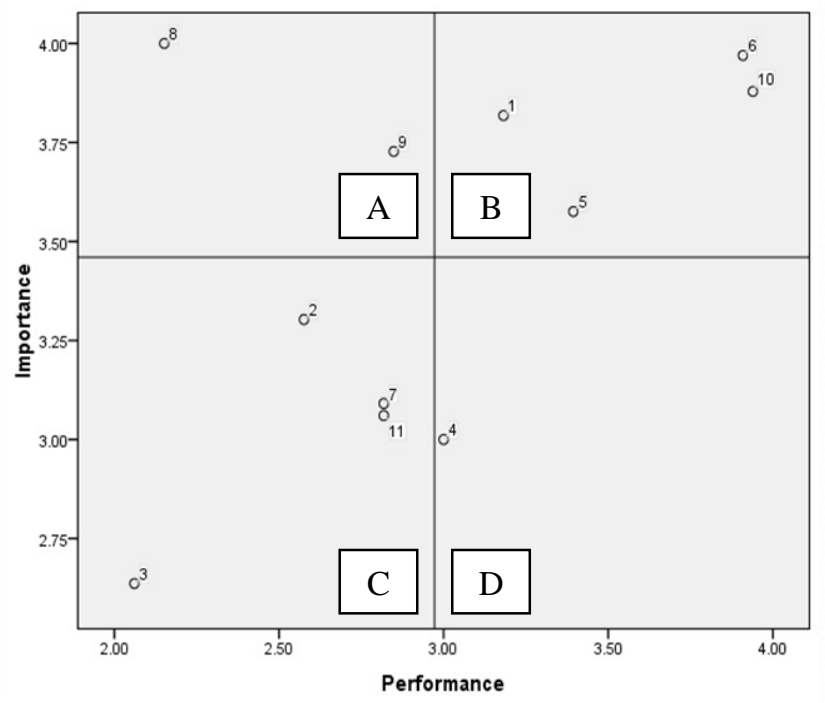

Figure 3. Improvement Priorities Diagram

As the Figure 3 shows, the attributes are placed on each quadran as each scores supposed to be.

a. Quadran A (Concentrate Here)

This quadran contains attributes which considered important by consumers, yet the performance is not fulfilling the expectations. The attributes are authencity sign (8) and price (9)

b. Quadran B (Keep Up The Good Work)

This quadran contains attributes which considered important and the performance are quite same as the expectations. The attributes are dependability (1), expired time (5), complaint managements (6), and brand name (10) 
c. Quadran C (Low Priority)

This quadran contains attributes which the performance are considered not good, and not important either. The attributes are volume variations (3), distribution permit (5), availability (7), and company reputation (11)

d. Quadran D (Possible Overkill)

This quadran contains the attributes which considerd not important, yet the performance felt too much by respondents. The attribute is usage instructions (4)

There are some similarities between this research with another satisfaction research, albeit with some adjustments because using SERVQUAL in determining the attributes. According Mazler et al (2003), there are some similarities between satisfaction on manufactured industry and service industry. Both customers on these industries seems to consider brand reputation already satisfying and needs to be maintained, because it is located in the same place which is the quadrant B (Mazler et al, 2003). Also both customer industries seem to consider the access/availability are not much important, and the performance are not quite good as well. Access/availability on both researches are located in quadrant C (Mazler et al, 2003).

\section{Whole Satisfaction Level}

The whole satisfaction level of Marshal 200 EC measured through CSI method. The results of of CSI is shown at Table 2 .

Table 2. CSI results

\begin{tabular}{cllc}
\hline No & Indicator & Attributes & $\begin{array}{c}\text { Weight } \\
\text { Score } \\
\text { (WS) }\end{array}$ \\
\hline 1 & Capability & Dependability & 0.32 \\
2 & Features & $\begin{array}{l}\text { Volume } \\
\text { variations }\end{array}$ & 0.22 \\
& Reliability & Distribution & 0.14 \\
& permit & \\
4 & Conformity & Usage & 0.24 \\
& & instructions & \\
5 & Durability & Expired time & 0.32 \\
6 & Servicea- & Complaints & 0.41 \\
& bility & management & \\
7 & & Availability & 0.23 \\
8 & Aesthetics & Authencity sign & 0.23 \\
9 & Perceived & Price & 0.28 \\
10 & quality & Brand name & 0.4 \\
11 & & Company & 0.23 \\
& & reputation & \\
\hline$\Sigma($ total) & & 3.01 \\
\hline Customer Satisfaction Index (\%) & 60.21 \\
\hline
\end{tabular}

Weight Scores (WS) of Marshal 200 EC is 3.01 and the following results of whole satisfaction which rose cultivators felt is 60.21 percent. Based on CSI scale which stated by Riandina and Nurmalina (2006), the whole satisfaction level of rose cultivators towards Marshal $200 \mathrm{EC}$ is at average satisfied category. The reason of this unpredictably low results is low level of suitability that rose cultivators felt towards the whole product.

\section{CONCLUSION AND SUGGESTION}

\section{Conclusion}

1) The continuous buying behavior of rose cultivators on Marshal 200 EC are caused by many factors. Family/relatives contribute meaningfully to inform the product. Association of the product which are efficient/potent and suitable/precisely fit to the rose cultivators' problem. The shop selection contributes on economical and psychological motives underlying the purchase decision. The high level of beliefs on the product is also involved. Consumers stated that they still will buy the product although the price rises.

2) Attributes which performance felt suitable to rose cultivators are usage instructions and brand name. Attributes that need high priorities for improvements are authencity sign and price. Attributes that need to be maintained are dependability, expired time, complaints management, and brand name.

3) The whole satisfaction level of Gunungsari Village's rose cultivators towards Marshal 200 $\mathrm{EC}$ is on average satisfied category.

\section{Suggestion}

Rose cultivators at Gunungsari Village should pay more attention to the usage instructions on all the chemical additives that have ben to put on the crops. The company could increase the the maximum satisfaction by researching more on the Marshal 200 EC products and the effects to white mealybugs (Pseudococcus sp.) as have been the applied usually by the Gunungsari Village's rose cultivators.

\section{REFERENCES}

Batt, Peter J. dan Aijun Liu. (2012). Consumer Behaviour Towards Honey Products in Western Australia. British Food Journal, Vol. 114 issue 2 pp. $285-297$.

Bitner, M.J. (1990) Evaluating Service Encounters The Effects of Physical Surroundings and Employee Responses. Journal of Marketing, 54, 69-82. 
Capitello, R., Agnoli, L., dan Begalli, D. (2015). Determinants of Consumer Behaviour in Novice Markets: The Case of Wine. Journal of Research in Marketing and Entrepreneurship Vol. 17 issue 1 pp. $110-126$.

Cerjak, M., Haas, R., Brunner F., dan Tomic, M. (2014). What Motivates Consumers to Buy Traditional Food Products? Evidence from Croatia and Austria Using Word Association and Laddering Interviews. British Food Journal Vol. 116 issue 11 pp. 1726 - 1747

Djojosumarto, P. (2008). Pestisida dan Aplikasinya. Agromedia Pustaka. Jakarta.

FranceAgriMer. (2013). Observatoire Mondial des Vins Roses. http://www.franceagrimer.fr. Diakses pada 26 Maret 2017.

Hafizah, Nur. (2014). Pertumbuhan Stek Mawar (Rosa damascina Mill.) pada waktu Perendaman dalam Larutan Urine Sapi. Ziraa'ah Volume 39 Nomor 3 Halaman 129135 ISSN Elektronik 2355-3545. http://www. ojs.uniska.ac.id. Diakses 31 Maret 2017.

Mustikarini, F., Retnaningsih, Simanjuntak M. (2014). Satisfaction and Loyalty to Pesticides among Paddy Farmers. Jur. Ilm. Kel. \& Kons., Mei 2014, p : 93-102 Vol. 7, No. 2 ISSN : 1907 $-6037$

Matzler, K., Sauerwein, E., and Heischmidt, K. (2013). Importance-Performance Analysis
Revisited: The Role of The Factor Structure of Customer Satisfaction. The Sevice Industries Journal Vol. 23 issue 2 pp. 112.

Riandina, Wahyu Oktaviani dan Rita Nurmalina Suryana. (2006). Analisis Kepuasan Pengunjung dan Pengembangan Fasilitas Wisata Agro. Jurnal Agro Ekonomi Volume 24 no. 1.

Rizzuto, Daniela and Reza Etemad-Sajadi. (2013). The Antecedents of Consumer Satisfaction and Loyalty in Fast Food Industry. International Journal of Quality \& Reliability Management Vol. 30 Issue 7 pp. $780-798$.

Schiffman, Leon dand Leslie Lazar Kanuk. (2008). Perilaku Konsumen, Edisi Ketujuh. PT. Indeks. Jakarta.

Tjiptono, F and Gregorius Chandra. (2008). Pemasaran Strategik. Penerbit Andi. Yogyakarta.

Yustitia, Adrina. (2009). Atribut Kepuasan Konsumen Produk Minuman Ringan CocaCola di Kota Bandar Lampung. Jurnal Teknologi dan Industri Hasil Pertanian Volume 14 No.1. Unit Program Belajar Jarak Jauh Universitas Terbuka. Bandar Lampung 